\title{
Fish products as protein supplements to cereals
}

\author{
BY K. J. CARPENTER AND GABRIELLE M. ELLINGER \\ Rowett Research Institute, Bucksburn, Aberdeenshire \\ AND MARGARET I. MUNRO AND E. J. ROLFE \\ Ministry of Agriculture, Fisheries and Food Research Establishment, Aberdeen
}

(Received 23 October 1956)

It is generally agreed that the protein fraction of fish is of high nutritive value, and that, as with other protein sources, this value is reduced by drastic processing methods (cf. review by Geiger, 1948). However, recent studies where fish products formed the sole protein source in a 'purified' diet showed very considerable reduction in nutritive value with drying procedures that have been generally regarded as relatively harmless (Bender, Miller \& Tunnah, I953; Miller, 1956). The present study was designed to provide similar information from tests of fish products in their practical role as supplements to cereals.

It was hoped also that the work would help (I) to indicate whether dehydrated fish, for human consumption, could undergo nutritional deterioration during storage and yet remain acceptable by the criteria of taste and appearance, and (2) to test further the use of a chemical determination for 'available lysine' which had shown promise as an indicator of protein quality (Carpenter \& Ellinger, $1955 b$ ).

\section{EXPERIMENTAL}

\section{Methods}

Measurement of colour. The test sample was finely ground and $3 \mathrm{~g}$ of the powder were lightly compressed into a standard porcelain tray. This was placed in a Lovibond Tintometer with a lens, to throw surface irregularities out of focus, interposed between the eyepiece and the sample. The colour was matched visually with the sets of standard coloured glass slides. Eye fatigue developed rapidly and necessitated rest between measurements: first impressions of colour difference were the most reliable. Colour intensity was expressed as the sum of 'red+yellow' units, as in other studies of browning reactions (Lea \& Hannan, i949).

The colour of samples could be intensified by covering their surface with liquid paraffin; but, whereas for pale materials the increase was approximately sixfold, it was only threefold for the darker ones. The procedure did not therefore improve discrimination and only the readings obtained with dry powders are given.

Determination of 'gross protein value'. The method has already been described in detail (Carpenter, Ellinger \& Shrimpton, 1955). It is a slight modification of a method the design and limitations of which were discussed by its originators (Heiman, Carver \& 
Cook, 1939). They suggested a standard method of evaluating supplementary proteins for chicks using a basal $8 \%$ protein ration of mixed cereals and vitamin concentrates. The supplements are added, for different groups, to give $3 \%$ of additional crude protein $(\mathrm{N} \times 6 \cdot 25)$. Their 'gross protein value' (G.P.V.) is the extra growth in $\mathrm{g}$ obtained in 2 weeks (i.e. the excess over growth on the basal ration) divided by the number of $g$ of supplementary protein eaten. The values are expressed as a percentage of that obtained for a standard casein within the same experiment.

The normal procedure was to include each test material in two trials, with the test ration being assigned to four groups of twelve chicks in each. That is to say the test material was fed to altogether ninety-six chicks, subdivided into eight groups. (However, with materials F, G, 'H+lysine' and $I$, either because three instead of four groups per treatment were included in a test, or in one trial because the numbers in each group were reduced to eight, the total chicks per treatment ranged from seventytwo to eighty-eight.) The design does not allow a straightforward statistical analysis of error within one experiment. An estimate of error has therefore been made from pairs of values obtained in replicated experiments.

Determination of 'available lysine'. This procedure has been described only in a preliminary communication (Carpenter \& Ellinger, 1955a). A quantity of ground material containing about $50 \mathrm{mg} \mathrm{N}$ was weighed accurately, transferred to a $100 \mathrm{ml}$. round-bottom flask with ground-glass stopper and suspended in $8 \mathrm{ml} .10 \%(\mathrm{w} / \mathrm{v})$ $\mathrm{NaHCO}_{3}$ for Io min. Fluoro-2:4-dinitrobenzene (a compound of vesicant properties that must be kept away from skin), $0.3 \mathrm{ml}$, was dissolved in $12 \mathrm{ml}$. ethanol and the solution added to the flask which was agitated gently in a mechanical shaker for $2 \mathrm{~h}$. The ethanol was then evaporated by unstoppering the flask and holding it in steam or boiling water until there was no further effervescence. Hydrochloric acid ( $24 \mathrm{ml}$., $5.5 \mathrm{~N}$ ) was added, by stages to reduce frothing, and the flask refluxed on a hot plate for $24 \mathrm{~h}$. It was then thoroughly cooled and the contents, with water washings, were filtered through paper and made up to $50 \mathrm{ml}$. with water. If time permitted at the cooling stage the flask was kept overnight in a refrigerator, since it helped to precipitate the excess fluoro-2:4-dinitrobenzene and reduce the subsequent work of extraction. A $5 \mathrm{ml}$. portion was shaken for I min in a separating funnel with $50 \mathrm{ml}$. diethyl ether, and the ether layer removed. This treatment was repeated a further three times. A $5 \mathrm{ml}$. portion of the last extract was shaken with I ml. $40 \%(\mathrm{w} / \mathrm{v}) \mathrm{NaOH}$, and if a yellow colour appeared the extraction procedure was continued. Finally, the aqueous layer was run off, together with additional $5.5 \mathrm{~N}-\mathrm{HCl}$ used to wash the funnel, and warmed in a beaker to evaporate dissolved ether.

After an addition of $\mathrm{I} \mathrm{ml}$. glacial acetic acid, to assist buffering, the $\mathrm{pH}$ was adjusted to $5( \pm 0.2)$ with $40 \%(\mathrm{w} / \mathrm{v}) \mathrm{NaOH}$, and the volume made up to $50 \mathrm{ml}$. with water. The liquid was then centrifuged, if necessary, to remove any suspension (which was occasionally present when the original material contained a high concentration of bone salts) and $5 \mathrm{ml}$. were diluted to $25 \mathrm{ml}$. with water. The extinction of the final solution was read in a Spekker absorptiometer in $1 \mathrm{~cm}$ cells with filter 6or (Hilger) having a maximum transmission at $435 \mu$. Provided solutions were kept out of direct sunlight during the work and stored in the dark, reading could be deferred for $24 \mathrm{~h}$ if necessary. 
For the full determination this procedure was followed in duplicate, and in parallel with a 'blank' in which the addition of fluoro-2:4-dinitrobenzene was omitted, $\mathrm{NaHCO}_{3}$ was replaced by the equivalent quantity of $\mathrm{NaOH}$ (to reduce frothing of the untreated protein on addition of acid) and the extinction was measured without the final fivefold dilution. In the blank runs a single shaking with ether gave an extract that remained colourless with alkali, and the extraction was not continued further.

Finally, the extinction was read of standard solutions of $\epsilon$-dinitrophenyl-lysine monohydrate monohydrochloride. Under the conditions of use, there was a linear concentration-extinction relationship for solutions buffered to $\mathrm{pH} 5$ and ranging in concentration from 12 to $28 \mu \mathrm{g} / \mathrm{ml}$., and a corresponding range of extinctions from approximately $\circ \cdot 18$ to 0.44 . The absolute values, expressed as $E_{1 \mathrm{~cm}}^{\mathbf{0} \cdot \mathbf{~} \%}$, had a mean of $14 \cdot 6$; and since the molecular weights of $\epsilon$-dinitrophenyl-lysine monohydrate monohydrochloride and lysine are 366.5 and $146 \cdot 1$ respectively, this value corresponds to an extinction of 36.67 for a solution deriving from I $\mathrm{mg}$ lysine $/ \mathrm{ml}$.

Because of the scarcity of dinitrophenyl-lysine at the time, a substandard of $5 \mathrm{mg} / \mathrm{ml}$. potassium dichromate was used for day-to-day checking of the instrument.

\section{Materials}

$A$ : vacuum-dried fillets. Cod (Gadus callarias) kept 2 days in ice were filleted, skinned and quick-frozen into blocks in a plate freezer. After holding them overnight at $-21^{\circ}$ to $-24^{\circ}$ the blocks were sawn into pieces, $2 \times 6.5 \times 10 \mathrm{~cm}$ and dried in vacuo (initial pressure I I $\mathrm{mm} \mathrm{Hg}$, falling gradually to $3.5 \mathrm{~mm}$ ) over a period of $8 \mathrm{~h}$. The maximum temperature within the fish was $60^{\circ}$; this temperature was reached and maintained for a short period at the end of the process (Gooding \& Rolfe, 1955; Hay, I955). The dehydrated cod fillets contained from $\mathrm{I} \cdot 7$ to $2 \cdot 3 \%$ moisture. They were nitrogenpacked in cans and stored at $-5^{\circ}$. The cans were opened immediately before required for the feeding tests and the contents milled to a powder.

$B$ : heated fillets $\left(55^{\circ} d r y\right)$. These were prepared from a portion of sample A, still packed in nitrogen, by raising the storage temperature to $55^{\circ}$ for $43 \mathrm{~h}$, and then returning it to $-5^{\circ}$.

$C:$ heated fillets $\left(100^{\circ} d r y\right)$. These were prepared similarly by holding them at $100^{\circ}$ for $3 \mathrm{I} \mathrm{h}$.

D: vacuum-dried fillets. These were further batches prepared in a similar way to those of sample $A$ for a second series of trials.

$E$ : heated fillets ( $105^{\circ}$ moist). These were prepared by exposing a portion of sample D to a humid atmosphere $\left(95 \%\right.$ r.h.) at $38^{\circ}$ for $90 \mathrm{~min}$ (a procedure designed to raise the moisture content to approximately $1 \mathrm{I} \cdot 5 \%$ ). They were then repacked in nitrogen and held at $105^{\circ}$ for $36 \mathrm{~h}$ before they were returned to storage at $-5^{\circ}$.

$F$ : spray-dried fish albumin. These were 'spray-dried extracted proteins prepared from whole white fish and offals' (Miller, 1956).

$G$ : acetone-dried fish waste. Minced white-fish offals $(40 \mathrm{lb}$.) were stirred with 8 gal. acetone, allowed to settle and the supernatant fluid was decanted. The treatment was repeated six more times, and the residual material spread out to dry in a current of air kept below $20^{\circ}$. 
H: white-fish meal. This was the material already described as no. 6 in a previous communication (Carpenter, Ellinger \& Shrimpton, 1954). It was prepared from fresh cod offal with initial drying for $3 \mathrm{~h}$ at $54^{\circ}$ in a 'batch-agitated' steam drier kept at reduced pressure ( $660 \mathrm{~mm} \mathrm{Hg}$ below atmospheric pressure), and final drying at $54^{\circ}$ rising to $93^{\circ}$ for $2 \frac{1}{2} h$ in a 'continuous-agitated' steam drier with a counter-current of ventilating air at atmospheric pressure.

I: white-fish meal. This meal was obtained as a random sample of commercially available material.

F: vacuum-dried fillets. These were similar to samples $\mathrm{A}$ and $\mathrm{D}$, but brought up to I $\%$ moisture content before being divided for various heat treatments. Three portions were repacked in nitrogen and stored at $-5^{\circ}$; but before storage two of the portions were held at $105^{\circ}$ for 24 and $48 \mathrm{~h}$ respectively. Two further portions were packed in air and also held at $1 \circ 5^{\circ}$ for 24 and $48 \mathrm{~h}$ respectively before being stored at $-5^{\circ}$. (These fillets were not fed to chicks.)

\section{RESULTS}

\section{Appearance of heated fillets}

Whereas the vacuum-dried material (samples A, D and J) was creamy-white, sample E, which received the most severe heat treatment, was a strong orange-yellow. The other treatments gave intermediate colours, as shown by the values for colour intensity in Tables $I$ and 2.

The vacuum-dried material was almost odourless when the cans were opened. All the heated samples smelt of ammonia, and with the more severely heated samples $\mathrm{H}_{2} \mathrm{~S}$ could also be detected; none, particularly samples $\mathrm{C}$ and $\mathrm{E}$, would normally have been considered acceptable for human consumption.

\section{Chick tests}

Table I shows the G.P.V.'s obtained with the test materials. Each value is the mean from two (or for sample $\mathrm{E}$ four) independent trials, and the standard error of each mean is $\pm 3 \cdot I$ ( 7 degrees of freedom), except for sample $E$ for which it is $\pm 2 \cdot 2$. The values obtained in series $\mathrm{I}$ for the fillets $\mathrm{B}$ and $\mathrm{C}$ which had been heated at $2-3 \%$ moisture content did not differ significantly from that of the unheated material A. However, in series 2, sample $E$, heated after increasing the moisture content, had a significantly lower nutritive value under the test conditions.

Samples $F$ and G, prepared by other low-temperature drying processes from mixed white fish and offals, and white-fish offals respectively, gave values within the range of the two samples of vacuum-dried fillets $A$ and $D$. The samples of white-fish meal $(\mathrm{H}$ and $\mathrm{I})$ gave values that were significantly $(P<0.05)$ lower by $7-12 \%$, but still superior to the value found for fillets exposed to $105^{\circ}$ at I I. $5 \%$ moisture content for $3^{6 \mathrm{~h}}$.

Supplementation of selected test rations with $0.21 \%$ L-lysine as the monohydrochloride (equivalent to fortifying the supplementary test protein with $7 \%$ L-lysine) increased the G.P.V. significantly $(P<0.05)$ with the heat-damaged fillets $(\mathrm{E})$ and the 
commercial fish meal $(\mathrm{H})$, but not with the vacuum-dried fillets $(\mathrm{D})$. The value obtained with the heat-damaged fillets $(E)$ when supplemented with lysine was still significantly $(P<0.05)$ lower than that of the control material (D) either with or without the addition of this amino-acid.

'Table I. Gross protein value, colour intensity and 'available lysine' of selected fish products

Sample

Gross protein value of product

fish products
$\begin{gathered}\text { Colour } \\ \text { intensity } \\ (r+y \text { units }) *\end{gathered}$$\overbrace{\begin{array}{c}\text { Without } \\ \text { added lysine }\end{array}}^{\begin{array}{c}\text { Gross protein value of product } \\ \text { (casein =100) }\end{array}} \underbrace{\begin{array}{c}\text { Available } \\ \text { lysine' } \\ (\mathrm{g} / \mathrm{r} 6 \mathrm{~g} \mathrm{~N})\end{array}}_{\begin{array}{c}\text { With added } \\ \text { lysine }\end{array}}$

Vacuum-dried fillets

Series I
A: control
B : $43 \mathrm{~h}$ dry heat at $55^{\circ}$
C: $31 \mathrm{~h}$ dry heat at $100^{\circ}$
$2 \cdot 5$
$101 \cdot 6$

$\begin{array}{ll}- & 7.92 \\ - & 7.77 \\ - & 6.96\end{array}$
$5 \cdot 8$
$104 \cdot 3$
$7 \cdot 92$
$7 \cdot 77$
$6 \cdot 96$

Series 2

D: control

E: $36 \mathrm{~h}$ moist heat at $105^{\circ}$

$2 \cdot 0$

II I. O

$106 \cdot 0$

$8 \cdot 18$

$10 \cdot 2$

$80 \cdot 4$

$9 \mathrm{I} \cdot 6$

$4 \cdot 94$

Other preparations

$F$ : spray-dried fish albumin

$G$ : acetone-dried fish waste

$\mathrm{H}$ : white-fish meal (commercial 'batchvacuum')

I: white-fish meal (random purchase)

$\begin{array}{rcc}102 \cdot 9 & - & - \\ 103 \cdot 3 & - & 7 \cdot 11 \\ 91 \cdot 3 & 110 \cdot 2 & 5 \cdot 75 \\ 96 \cdot 1 & - & 6.26\end{array}$

* See p. I62.

Table 2. Colour intensity and 'available lysine' of sample $\mathcal{F}$ (vacuum-dried fillets) before and after heat treatment at $105^{\circ}$ in either nitrogen or air

\begin{tabular}{|c|c|c|c|c|}
\hline $\begin{array}{l}\text { Period } \\
\text { at } 105^{\circ} \\
\text { (h) }\end{array}$ & $\begin{array}{c}\text { Atmosphere } \\
\text { during } \\
\text { heating }\end{array}$ & $\begin{array}{l}\text { Final } \\
\text { moisture } \\
\text { content } \\
(\%)\end{array}$ & $\begin{array}{c}\text { Colour } \\
\text { intensity } \\
(r+y \text { units })^{*}\end{array}$ & $\begin{array}{c}\text { Available } \\
\text { lysine' } \\
(\mathrm{g} / \mathrm{I} 6 \mathrm{~g} \mathrm{~N})\end{array}$ \\
\hline $\mathrm{Nil}$ & 一 & 10.7 & $I \cdot 4$ & $7 \cdot 52$ \\
\hline 24 & Nitrogen & I I 2 & $6 \cdot 9$ & $5 \cdot 30$ \\
\hline 24 & Air & $12 \cdot I$ & 9.0 & $5 \cdot 24$ \\
\hline 48 & Nitrogen & 10.5 & 9.4 & 3.77 \\
\hline 48 & Air & 10.6 & 10.5 & 3.76 \\
\hline \multicolumn{5}{|c|}{ * See p. 162.} \\
\hline \multicolumn{5}{|c|}{ 'Available lysine' } \\
\hline
\end{tabular}

No difficulty was found in the application of the fluoro-2:4-dinitrobenzene method to the test materials, and the 'available lysine' values for each sample except $F$ (none of which was retained for analysis) are given in Table $\mathrm{x}$. The values show a close relationship to those found in the chick experiments. In both sets of experiments sample $D$ had the highest value. Samples $A, B, C$ and $\mathrm{G}-$-all with gross protein values close to roohad available lysine values in the range $7 \cdot 0-7 \cdot 9$, and those of lowest value for chicks, 
$\mathrm{I}, \mathrm{H}$ and $\mathrm{E}$ (in descending order), had available lysine values of $6.3,5.8$ and $4.9 \mathrm{~g} /$ $16 \mathrm{~g} \mathrm{~N}$ respectively. This relationship is illustrated graphically and compared with all the available data on other materials (Carpenter \& Ellinger, $1955^{b}$ ) in Fig. I.

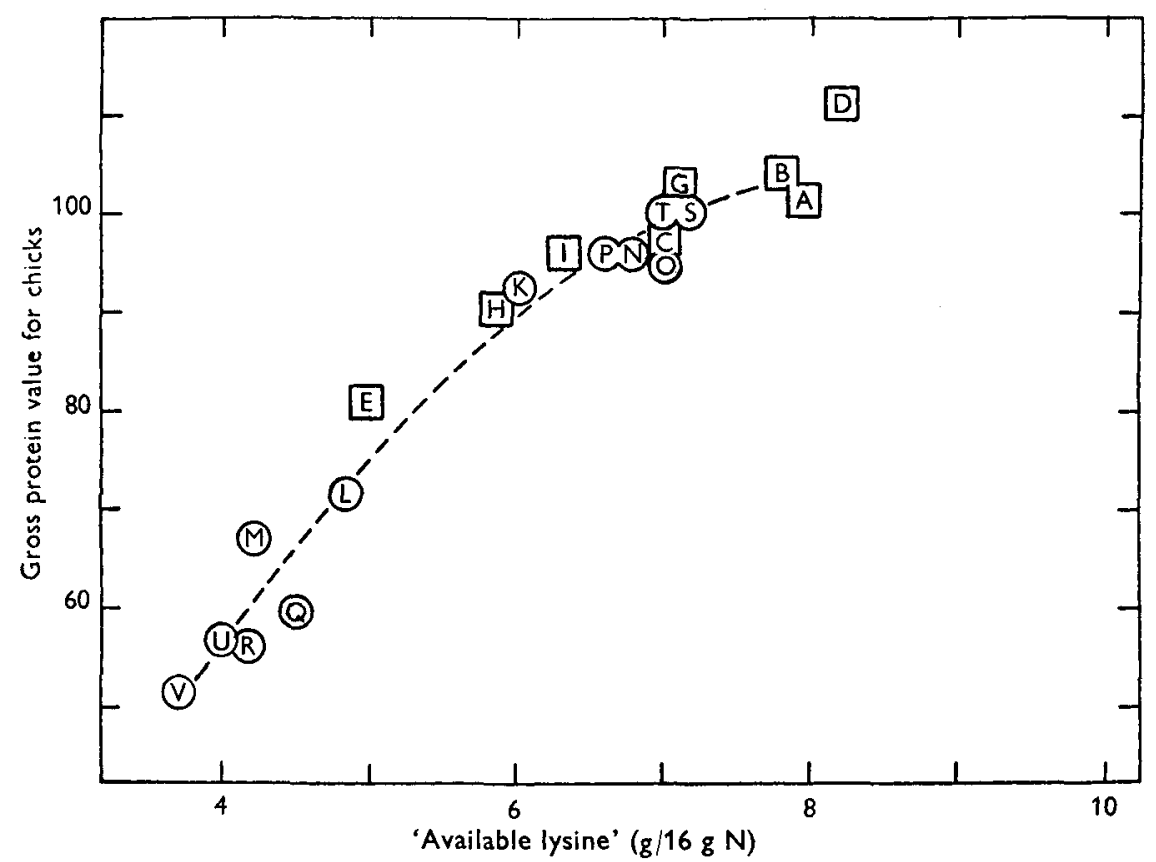

Fig. I. Chemical values for 'available lysine' and biological 'gross protein values' of test materials. The values for samples $\mathrm{A}-\mathrm{E}, \mathrm{G}, \mathrm{H}$ and $\mathrm{I}$ (in squares) are taken from Table $\mathbf{I}$; values for the remaining samples (in circles) come from an earlier publication (Carpenter \& Ellinger, $1955 b$ ) with the following code: $\mathrm{K}$, herring meal (367); L, pilchard meal (492); $\mathrm{M}$, condensed herring solubles (233); $\mathrm{N}$, whale-meat meal ( 190$)$; $\mathrm{O}$, whale-meat meal (I88); $\mathrm{P}$, grax meal (25I); $\mathrm{Q}$, whale meat-and-bone meal (189); R, condensed whale solubles (198); S, casein, alcohol-extracted (361); T, casein (537); $\mathrm{U}$, meat-and-bone meal (392); V, gelatin, commercial (489). The figures in parentheses in the code are reference numbers quoted by Carpenter $\&$ Ellinger (r955 $b$ ). The inset regression line, ---- , $\left(y=43 \cdot 8 x-2 \cdot 69 x^{2}-75 \cdot 5\right)$ was that found to give the best fit for the earlier values.

\section{DISCUSSION}

\section{Degree of damage in fish meals}

In earlier work samples of white-fish meals prepared by different methods all gave gross protein values in the range 85-95 (Carpenter et al. 1954). These corresponded generally to the findings of other workers for the better commercial meals, made from either white or 'oily' fish (cf. review by Duckworth, 1955), and the figures obtained here for the two white-fish meal samples (H and I) are of the same order. It is clear also that the value of fish meals prepared less carefully can be much lower, but our first interest was to obtain an estimate of how far the best commercial product still fell short of an 'ideal' material in G.P.v. The first materials chosen for comparison were cod fillets (i.e. muscle without skin or bone) that had been vacuum-dried and stored under refrigeration in an atmosphere of nitrogen, and they ( $A$ and D) showed a mean value of 106. Since two other samples (B and $G$ ) prepared from whole fish and fish waste at low temperatures 
also gave values over 100, it seems that the treatment of the fish (including the method of storage as well as of processing), rather than the nature of the raw material, must have been responsible for the higher figures. The value of commercial fish meals as protein supplements for cereals leaves room for improvement, therefore, since they fall 10-1 $5 \%$ short of other products from similar material.

However, these findings still differ from those of Bender et al. (1953) where the net protein utilization (N.P.U.) for rats of two samples of white-fish meal were 26 and $31 \%$ respectively below the corresponding figure for vacuum-dried cod. This apparent discrepancy may arise from the different measures of protein quality that were used. The first property the two tests have in common is that they give a value of zero for a protein making no contribution to the economy of the test animal-in contrast to the measurement of protein efficiency ratios (P.E.R.) in which low-quality proteins give negative results, and for which it would be expected that if fish meals gave values for N.P.U. that were only $70 \%$ of the values found for vacuum-dried cod, then the corresponding P.E.R. would be less than $50 \%$ that of the reference material (cf. Bender, 1956).

We have used the test materials as supplements to a basal ration containing cereal protein (and some additional protein from yeast and whey) for chicks, but in the other method the test materials were used as the sole protein source in the experimental diets for rats. There is reason to expect different amino-acids to be limiting under these conditions (Carpenter, 195I). In the present experiments lysine was the limiting amino-acid in a test ration containing fish meal $\mathrm{H}$, and in N.P.U. tests the limiting amino-acid with each of a series of fish meals was methionine (Miller, r956). To explain the greater fall in value in the N.P.U. tests on this basis, methionine (or cystine and methionine) would have to be particularly subject to destruction (or to being made unavailable) during processing. There is some support for this idea in the finding that whereas the N.P.U. values of five meals unsupplemented ranged from $33 \cdot 0$ to $61 \cdot 4$, a difference of $28 \cdot 4$; after supplementation with methionine the range was only $20.7(48 \cdot 8-69 \cdot 5)$ (Miller, 1956). In other words the decrease through the series when methionine was the limiting factor (as shown by a response to this amino-acid) was slightly greater than when performance was limited by the second limiting aminoacid or acids (i.e. in the presence of added methionine).

Lastly the fish meals and the vacuum-dried materials used in the two studies may not have corresponded in their properties. Grau \& Williams (I955) have demonstrated that differences in the value of fish meals as sole protein sources cannot always be explained in a simple way by the type of processing they receive; and Robertson, Carver \& Cook (1940) have also reported exceptionally high G.P.v. values for one particular batch of meals.

It is in any event impossible to choose a single numerical scale of 'protein quality' that will be applicable in every practical situation. However, experience seems to indicate that lysine and 'cystine + methionine' are the most likely amino-acids to be limiting in practical rations, so that G.P.V. and N.P.U. values which seem to depend on the adequacy of lysine and the sulphur amino-acids respectively should, taken together, give an indication of the practical limitations of particular materials. 


\section{Dehydrated fillets for human consumption}

The G.P.V. tests confirmed the expectation that this type of dehydrated material could form a high-quality source of dietary protein. There was a slight variation in colour, 'available lysine' content and G.P.v. between the samples tested, which may reflect differences in storage time before use. However, even when the material, as normally stored at $2-3 \%$ moisture content, was heated sufficiently for it to appear grossly deteriorated (sample C), the change in G.P.v. was slight. The indication is therefore that significant nutritional deterioration, due to heat damage in storage, is unlikely to pass undetected.

Miller (1956) has reported that fish proteins are more readily damaged at higher moisture content. This aspect was studied in our second series of tests (Table $\mathbf{r}$ ), and significant nutritional damage was demonstrated - though again the foul smell and very dark colour of the heated material $E$ suggested at the time that considerably more damage would be found than that represented by a $28 \%$ drop in G.P.V.

Since the G.P.V. of the heated fillets $\mathrm{E}$ was significantly increased by the addition of lysine, this amino-acid appears to have become the first limiting factor, and to have been particularly damaged. This effect is underlined by lysine not having been the limiting factor (or, at any rate, the sole limiting factor) with the control fillets D since with them its addition did not significantly change the G.P.V. However, lysine cannot have been the only amino-acid affected by processing since the G.P.V. of fillets $\mathrm{E}$, even with added lysine, was below that of the control material $D$.

With this limited series of materials the colour intensity was a good guide to the degree of damage incurred. However, in the fillets $J$ that were heated in the presence of oxygen (Table 2) there was a suggestion of increased browning without a parallel increase in the binding of the $\epsilon$-amino-groups of lysine.

\section{'Available lysine'}

There is considerable evidence that conventional analysis for lysine in acid hydrolysates of processed materials may fail to give figures of value in predicting their nutritional value even under conditions where lysine is the limiting amino-acid (cf. National Research Council: Food and Nutrition Board, r950). Our investigation of the fluorodinitrobenzene reaction with $-\mathrm{NH}_{2}$ groups as a possible tool for tackling this problem was based on the many suggestions in the literature that the reduced availability of lysine in processed materials was due to the formation of complexes that were resistant to enzymic attack (e.g. Henry, Kon, Lea \& White, r947-8; Almquist \& Maurer, 1953). In particular, fluoro-2:4-dinitrobenzene has been used in a basic study of the reaction of purified sodium caseinate and glucose (Lea \& Hannan, 1950) with the finding that a reduction in number of free $\epsilon$-amino-groups of lysine was accompanied by a fall in nutritional value (Henry \& Kon, 1950).

We have followed the original conditions of Sanger (1945) for the reaction of fluoro2:4-dinitrobenzene with a purified protein, but have used the crude materials directly and have continued the procedure with the whole digest instead of using only precipitated dinitrophenyl protein. Again, after acid hydrolysis of the reaction products we 
have endeavoured to avoid the necessity for chromatographic separation of $\epsilon$-dinitrophenyl-lysine on a silica-gel column (which would make the procedure too complex to be considered for routine use in general analytical laboratories) by extraction with diethyl ether. Repeated extraction with this solvent removes excess fluoro-2:4dinitrobenzene, the breakdown products dinitroaniline and dinitrophenol and the ether-soluble dinitrophenyl amino-acids. Of all the coloured dinitrophenyl amino-acids only $\alpha$-dinitrophenylarginine, bis-dinitrophenylhistidine and $\epsilon$-dinitrophenyl-lysine would be expected to remain in the aqueous phase (Sanger, 1945). Modern work supports the suggestion that the only free reacting amino-groups to be expected in intact proteins are the $\epsilon$-lysine group, and the terminal $-\mathrm{NH}_{2}$ residue at one end of each polypeptide chain (Chibnall, 1942) so that one would expect the histidine and arginine derivatives to contribute little to the residual colour. The proportion of lysine in the same terminal position with the $\epsilon$-amino-group free, so that it would form the ethersoluble bis-dinitrophenyl-lysine, should also be small. These expectations would not, of course, apply for highly degraded starting material that contained free amino-acids or even short-chain peptides. Collagens present in animal-protein concentrates may also contribute some $\epsilon$-dinitrophenylhydroxylysine (Solomons \& Irving, 1956). It is also possible that other coloured compounds will be formed and fail to be extracted with ether, although we could not differentiate any such interfering products, with the test materials considered here, by paper chromatography with butanol-acetic acid (Sanger \& Tuppy, 195 I ). (When the method has been applied to vegetable foods and fermentation products, interfering products have been detected in this way.) We preferred to read the extinction of the final solution in the visible region at $435 \mathrm{~m} \mu$, although the maximum absorption of $\epsilon$-dinitrophenyl-lysine is at about $370 \mathrm{~m} \mu$ (Sanger, 1949), because of the greater likelihood of interference and the difficulty of detecting it outside the visible range.

Finally there remain the possibilities of an incomplete initial reaction of fluoro-2:4dinitrobenzene with all the free $\epsilon$-amino-groups, and then a partial breakdown of $\epsilon$ dinitrophenyl-lysine during refluxing. Therefore, although the method has had a stronger line of reasoning in its development than, say, the purely empirical 'protein quality index' (Almquist, Stokstad \& Halbrook, I935), it can still be evaluated only by the extent to which it yields values having a relationship to nutritional values determined with experimental animals. With the twenty samples tested in this work the relationship has been close, as shown in Fig. I, and for further materials of the same type one could expect to predict their G.P.V. from this purely chemical determination to within \pm 5 units (Carpenter \& Ellinger, $1955^{b}$ ).

It is important to note that the relationship continued to hold for the heat-treated fillets $\mathrm{E}$ that were kept out of contact with oxygen while being damaged. The results shown in Table 2 indicate that the presence or absence of oxygen has little effect on the loss of reactive $\epsilon$-amino-groups during processing.

The shape of the regression curve in Fig. I suggests that for materials having an 'available lysine' value of over $7 \mathrm{~g} / 16 \mathrm{~g} \mathrm{~N}$ lysine is no longer the first amino-acid limiting the chick's performance in a G.P.V. test. This suggestion was supported by the failure of a dietary supplement of lysine to improve the G.P.v. of the vacuum-dried 
fillets D. In fact, the supplemented ration had a slightly lower G.P.v. Even though the difference was not statistically significant, it may on repetition prove to be another example of a growth depression caused by the dietary addition of an amino-acid other than that first limiting performance (cf. review by Harper, I956).

In a separate study the heat-damaged fillets $\mathrm{E}$ and the control fillets $\mathrm{D}$ have been analysed for 'total lysine' with preliminary acid hydrolysis and separation on a resin column by a modification of the Moore $\&$ Stein (I95I) procedure, to give values of 8.8 and $9.9 \mathrm{~g} / 16 \mathrm{~g} \mathrm{~N}$ respectively (Ellinger, $195^{6}$ ): the corresponding 'available lysine' values were 4.9 and $8.2 \mathrm{~g} / \mathrm{1} 6 \mathrm{~g} \mathrm{~N}$. This finding is in line with those of other workers that a fraction of the lysine which became resistant to enzymic release as a result of heat damage was also not recoverable by acid hydrolysis (Mauron, Mottu, Bujard \& Egli, I955). However, the reduction in 'total lysine' content is not sufficient to explain the severe fall in nutritional value after heat treatment.

\section{The mechanism of heat damage}

Miller (1956) has concluded that the reduced value of heated fish products is to be explained by the formation of amino-acid-sugar complexes resistant to digestion. Other workers have concluded that, for foods in general, "evidence at hand suggests that the "browning reaction" of Maillard, although definitely related to the problem is not the actual cause of injury' (National Research Council: Food and Nutrition Board, 1950).

In model casein-glucose systems, and in dried skim milk it has been demonstrated that 'free sugar' declines in quantities equivalent to the fall in number of reactive amino-groups. There is no evidence that fish products contain carbohydrates in the order of concentration required to explain in this way the $28 \%$ reduction in value of the heated fillets $\mathrm{E}$ in the present series. On the most conservative estimate we would have to assume that $6 \%$ of the dry weight of the material was made up of amino-acids (such as lysine or the sulphur amino-acids) combined with sugars having the same order of weight.

Tarr (I 953) has demonstrated that free ribose is present post mortem in the tissues of certain species of fish, and that the development of browning is paralleled by a fall in the level of this sugar. However, the maximum level of ribose (found in Pacific ling cod) was $0.4 \%$ of the dry-matter content, and when it was removed browning failed to occur ('Tarr \& Bissett, r954), which suggests that no other 'browning' sugars were present in significant quantities. There is considerable difference between species ('Tarr, 1954), but examination has shown little pentose, less than $0.1 \%$ glucose and no detectable quantity of free glucuronic acid or other carbohydrate in the type of cod fillets used in our studies (Jones, 19566 ). Here some of the coloration, which was orange rather than brown, is to be explained by the production of degradation products of methylhistidine (Jones, $1956 a, b$ ).

Our finding of a correlation between nutritive value and the number of free 'lysine $\epsilon$-amino-groups' cannot therefore be considered as supporting the hypothesis that heat damage to proteins can always be explained simply in terms of the formation of aminoacid-sugar complexes. The full nature of the phenomenon remains to be unravelled. 


\section{SUMMARY}

I. A number of dehydrated fish products were tested as supplementary proteins to cereals by the standard 'gross protein value' technique with chicks. Those prepared for human consumption proved superior to the casein that was used as the standard.

2. Commercial fish meals gave values approximately 10\% below those of preparations made by low-temperature drying processes.

3. The value of vacuum-dried cod fillets, packed in nitrogen at $2-3 \%$ moisture content, was not significantly reduced by holding the product at $100^{\circ}$ for $3 \mathrm{I} \mathrm{h}$ despite considerable browning and formation of ammonia.

4. Similar fillets raised to i $\%$ moisture content and held at $105^{\circ}$ for $36 \mathrm{~h}$ showed reduction of approximately $28 \%$ in nutritive value.

5. The addition of lysine to the heat-damaged fillets and to a commercial fish meal raised their value; no such effect was obtained with high-quality vacuum-dried fillets.

6. A chemical measure of 'available lysine' obtained by reaction of the test materials with fluorodinitrobenzene and subsequent estimation of $\epsilon$-dinitrophenyl-lysine after hydrolysis showed a close relationship with the biological results.

We wish to express our gratitude to Mr G. Carpenter (Association of Fish Meal Manufacturers), Mr H. J. Gregson (Isaac Spencer Ltd) and Mr D. S. Miller (Crookes Laboratories Ltd) for their help in preparing and supplying experimental materials; to Miss Ria McDonald for carrying out the 'available lysine' determinations, and to Dr R. L. M. Synge for advice on the development of this procedure.

\section{REFERENCES}

Almquist, H. J. \& Maurer, S. (1953). Poult. Sci. 32, 549 .

Almquist, H. J., Stokstad, E. L. R. \& Halbrook, E. R. (1935). F. Nutr. ro, r93.

Bender, A. E. (1956). Brit. F. Nutr. Io, I35.

Bender, A. E., Miller, D. S. \& Tunnah, E. J. (1953). Proc. Nutr. Soc. 12, ii.

Carpenter, K. J. (I95I). Brit. F. Nutr. 5, 243.

Carpenter, K. J. \& Ellinger, G. M. (r955a). Biochem. F. 6r, xi.

Carpenter, K. J. \& Ellinger, G. M. (1955b). Poult. Sci. 34, 145 I.

Carpenter, K. J., Ellinger, G. M. \& Shrimpton, D. H. (I954). Proc. Nutr. Soc. r3, xx.

Carpenter, K. J., Ellinger, G. M. \& Shrimpton, D. H. (1955). F. Sci. Fd Agric. 6, 296.

Chibnall, A. C. (1942). Proc. roy. Soc. B, 131, 136.

Duckworth, J. (I955). F. Sci. Fd Agric. 6, 240.

Ellinger, G. M. (1956). Unpublished results.

Geiger, E. (I948). Fortschr. Chem. org. Naturst. 5, 267.

Gooding, E. G. B. \& Rolfe, E. J. (1955). F. Sci. Fd Agric. 6, 427.

Grau, C. R. \& Williams, M. A. (r955). Poult. Sci. 34, 8 го.

Harper, A. E. (1956). Nutr. Rev. 14, 225.

Hay, J. M. (1955). Ұ. Sci. Fd Agric. 6, 433.

Heiman, V., Carver, J. S. \& Cook, J. W. (1939). Poult. Sci. 18, 464.

Henry, K. M. \& Kon, S. K. (r950). Biochim. biophys. acta, 5, 455.

Henry, K. M., Kon, S. K., Lea, C. H. \& White, J. C. D. (1947-8). F. Dairy Res. 15, 292.

Jones, N. R. (1956a). Nature, Lond., r77, 748.

Jones, N. R. (1956b). Private communication.

Lea, C. H. \& Hannan, R. S. (1949). Biochim. biophys. acta, 3, 3 I 3 .

Lea, C. H. \& Hannan, R. S. (1950). Biochim. biophys. acta, 4, 5 I8.

Mauron, J., Mottu, F., Bujard, E. \& Egli, R. H. (1955). Arch. Biochem. Biophys. 59, 433.

Miller, D. S. (1956). F. Sci. Fd Agric. 7, 337. 
Moore, S. \& Stein, W. H. (1951). F. biol. Chem. 192, 663.

National Research Council: Food and Nutrition Board (1950). Repr. nat. Res. Coun., Wash., no. 131.

Robertson, E. I., Carver, J. S. \& Cook, J. W. (1940). Bull. Wash. St. agric. Exp. Sta. no. $3^{88 .}$

Sanger, F. (1945). Biochem. F. 39, 507.

Sanger, F. (1949). Biochem. Y. 45, 563 .

Sanger, F. \& Tuppy, H. (I95I). Biochem. F. 49, 463.

Solomons, C. C. \& Irving, J. T. (1956). Nature, Lond., 178, 548 .

Tarr, H. L. A. (1953). Nature, Lond., I71, 344.

Tarr, H. L. A. (1954). Food Tech. 8, i 5.

Tarr, H. L. A. \& Bissett, H. M. (1954). Progr. Rep. Pacif. Coast Stas Nanaimo \& Vancouver, no. 98, p. 3 .

\title{
Some observations on the biological assay of vitamin $A$ and its precursors by the vaginal-smear method
}

\author{
By PAMELA M. CLARKE AND PAMELA E. E. TODD \\ National Institute for Research in Dairying, Shinfield, near Reading \\ (Received 23 October 1956)
}

The dekeratinizing effect of vitamin A on the vaginal epithelium of the rat was reported by Evans $\&$ Bishop (1922), and various attempts have been made since 1930 to use it as a basis for a biological assay of the vitamin and its precursors. In particular, Pugsley, Wills \& Crandall (r944) have described a method suitable for routine purposes, wherein a quantitative response is given by the number of days needed by depleted rats to become re-depleted after dosing with the vitamin. The method has several attractive features: notably that the response is more specific than in other methods of vitamin A assay, and that the method is economical in that the same animals may be used repeatedly. A further advantage is that the criterion of vitamin A depletion, the characteristic cornified-cell smear, is easily recognized, whereas the corresponding criterion in the assay based on body-weight is poorly defined (see, for example, Bliss \& György, 1951).

In spite of these advantages, however, the vaginal-smear method does not appear to be widely used. Recently we employed it in a series of assays of the biological activity of materials containing isomers of vitamin A: our experience is reported here, to draw attention to the method and to the fact that we found it possible to assume a simpler relationship between dose and response than that used by Pugsley et al. (1944), so that the analysis of the results was also simpler. Some points affecting the design of the assay will also be discussed.

\section{EXPERIMENTAL}

\section{Management of rats}

With only slight adaptations of diets and procedures to those customary in our laboratory, we followed closely the technique of Pugsley et al. (1944). 